\title{
PRELIMINARY PHYTOCHEMICAL SCREENING AND TO EVALUATE ANTI-OXIDANT PROPERTY ON ROOT EXTRACT OF DILLENIA INDICA (ELEPHANT APPLE)
}

\author{
BIDISHA BORDOLOI*, SUMIT DAS
}

Department of Pharmaceutical Sciences, Girijananda Chowdhury Institute of Pharmaceutical Science (GIPS), Azara, Hatkhowapara, NH37, Guwahati, Assam 781017

Email: bidibordoloi@gmail.com

Received: 19 Apr 2019, Revised and Accepted: 26 Jun 2019

\section{ABSTRACT}

Objective: The objective of the present study was to carry out the presence of antioxidants activity on root extract of Dilleniaindica (FamilyDilleniaceae) which is believed to have the protective mechanisms in beneficial health effects.

Methods: Considering its medicinal importance, the plant was chosen for extraction with various solvents such as petroleum ether, chloroform and ethanol which was taken into considerations to determine the phytochemicals analyses present in it. The extracts of the roots were evaluated for antioxidant activity by using different in vitro models like Reducing Power method, TBA Method and DPPH method at different doses $(20,50,100,200,400 \mu \mathrm{g} / \mathrm{ml})$. The ic50 values of each extract on different activity were carried out.

Results: The study shows that petroleum ether, chloroform and ethanolic extract of this plant showed potent antioxidant activity against the standard drug (Ascorbic acid). But chloroform extract of the roots shown most significant anti-oxidant activity as compared to petroleum ether and ethanol.

Conclusion: The root part of the plant shows active anti-oxidant activity that can be consumed by mankind.

Keywords: Phytochemical screening, Pharmacognostic evaluation, Anti-oxidant activity

(C) 2019 The Authors. Published by Innovare Academic Sciences Pvt Ltd. This is an open-access article under the CC BY license (http://creativecommons.org/licenses/by/4.0/) DOI: http://dx.doi.org/10.22159/ijcpr.2019v11i4.34957

\section{INTRODUCTION}

In the last few decades, traditional knowledge on primary healthcare has been widely acknowledged across the world. It is estimated that $60 \%$ of the world population and $80 \%$ of the population of developing countries rely on traditional medicine, mostly plant drugs, for the primary health care needs. The herbal products today symbolize safety in contrast to the synthetics that are regarded as unsafe to human and environment $[1,2]$.

Use of plants as a source of medicine has been inherited and is an important component of the health care system in Egypt. Ayurveda, Siddha, Unani and Folk (tribal) medicines are the major systems of indigenous medicines. Among these systems, Ayurveda is the most developed and widely practiced in India. Today this system of medicine is being practiced in countries like Nepal, Bhutan, Sri Lanka, Bangladesh and Pakistan. This ancient system of medicine, believed to be more than $5000 \mathrm{y}$ old, is based on two separate theories about the natural laws that govern good health and longevity, namely yin and yang, and the five elements (wu xing). Chinese medicine was systematized and written between 100 and $200 \mathrm{BC}$.

The Dillenia indica is comprised of about 100 species of evergreen and deciduous trees or shrubs of disjunct distribution in the seasonal tropics of Madagascar through South and South East Asia, Malaysia, North Australia. Mucilage from their fruits is used in drug formulations. Species from this have been widely used in medicinal folklore to treat cancers, wounds, jaundice, fever, cough, diabetes mellitus, and diarrhea as well as hair tonics. It also produces edible fruits and are cultivated as ornamental plants. Their extracts and pure compounds have been reported for their antimicrobial, antiinflammatory, cytotoxic, ant diabetes, antioxidant, antidiarrheal, and antiprotozoal activities [3, 4].

\section{MATERIALS AND METHODS}

\section{Collection of plant material}

The roots of Dillenia indica were collected in the month of Feb, 2019 from Sivasagar, Assam.

\section{Authentication of plants material}

The plant is authenticated by Department of Botany Guwahati University.

Drying and grinding of plant material

After authentication of the plant, the roots were shade dried and grinded. The material which is retained on the sieve was used for the extraction purpose.

\section{Extraction of active constituents}

The process of removing or extracting or separating of active constituents from the crude drugs by using suitable solvents is called extraction. The active constituents that have been extracted from crude drugs are known as extractives and the preparation so obtained are as extracts. About 400g of the powder of the roots of Dilleniaindica was weighed and extracted successively with the soxhlet apparatus. At first, it was extracted with petroleum ether and then according to their polarity lower to higher with ethanol and chloroform, respectively. The extract collected was filtered and evaporated using distillation.

\section{Preliminary phytochemical screening}

The chemical evaluation of different extracts was done by using a various standard procedure of different metabolites like alkaloids, tannins, saponins, glycosides, carbohydrates, flavonoids, proteins, ascorbic acid (vit c), phenolics. The results are shown in table 1:[6]

\section{Pharmacognostic evaluation}

Determination of loss on drying

Procedure

- Weight about $1.5 \mathrm{~g}$ of the powdered drug into a weighed flat and thin porcelain dish.

- Dry in the oven at 100-degree C, until two consecutive weighings do not differ by more than $0.5 \mathrm{mg}$. 
- Cool in a desiccator's and wt. (The loss in wt. is usually recorded as moisture.)

The results are shown in table 2.

\section{Determination of moisture content}

Procedure

- About 5 gm of air-dried crude drug was accurately weigh in a watch glass.

- The drug was kept in hot air woven at $105{ }^{\circ} \mathrm{C}$ and dry for a period until constant weigh obtained.

- The difference in weigh gives the moisture content of the drug.

The results are shown in table 3.

\section{Determination of foaming index}

\section{Procedure}

- Take $1 \mathrm{~g}$ of coarse powdered drug in $500 \mathrm{ml}$ conical flask.

- Add $100 \mathrm{ml}$ boiling water and maintain moderate temperature for boiling for $30 \mathrm{~min}$.

- Cool and filter into a volumetric flask and add water up to 100 $\mathrm{ml}$.

- Take 10 test tubes with successive portions of 1,2 to $10 \mathrm{ml}$ drug in each tubes.

- Adjust the volume with water up to $10 \mathrm{ml}$ in each tubes and close the tubes with stoppers.

- Shake them for 15 seconds and allow to stand for $15 \mathrm{~min}$. then measure the height.

The results are shown in table 4

\section{Determination of swelling index}

\section{Procedure}

- Take $1 \mathrm{~g}$ of the powder in a $25 \mathrm{ml}$ stoppered cylinder.

- Adding water up to $25 \mathrm{ml}$.

- Shake occasionally for $23 \mathrm{~h}$.

- $\quad$ Keep aside for $1 \mathrm{~h}$.
- The volume of the mixture in $\mathrm{ml}$ is then read.

The results are shown in table 5.

\section{Determination of ash values of a crude drug}

- Use to determine the quality and purity of a crude drug and to establish the identity of it.

- Used to determine foreign inorganic matter present as an impurity.

- $\quad$ The results are shown in table 6 .

\section{Determination of fluorescence powder drug analysis}

In the present study, dry root powder was used. The fluorescent analysis of the root powder of the plant Dillenia indica was carried out. The root of the plant after drying were then blended using a electric blender. This fine powder was analyzed for the fluorescent.

The results are shown in table 7 [5-6].

Chemical studies

Determination of \% yield: It is done by following the formula

$$
\% \text { of yield }=\text { Practical yield } \times 100
$$

Theoretical yield

The results are shown in table 8.

\section{In vitro anti-oxidant studies}

\section{Reducing power assay method}

\section{Procedure}

Taking $1 \mathrm{ml}$ of methanolic extract $(100-400 \mu \mathrm{g} / \mathrm{ml})$, standard dilutions (20-400 $\mu \mathrm{g} / \mathrm{ml})$ and control sample (1 ml distilled water instead of sample solution) was mixed with $2.5 \mathrm{ml}$ phosphate buffer solution ( $\mathrm{pH} 6.6$ ) and $2.5 \mathrm{ml}$ potassium ferricyanide (1\%). Then the final mixture was properly mixed and incubated at $50{ }^{\circ} \mathrm{C}$ for $20 \mathrm{~min}$. After incubation, the reaction mixture was rapidly cooled and mixed with $2.5 \mathrm{ml}$ of $10 \%$ trichloroacetic acid. It was then centrifuged at $3000 \mathrm{rpm}$ for $10 \mathrm{~min}$. About $2.5 \mathrm{ml}$ of the supernatant was taken, and $2.5 \mathrm{ml}$ distilled water and $0.5 \mathrm{ml}$ of ferric chloride $(0.1 \%)$ were added, mixed well and allowed to stand for $10 \mathrm{~min}$. The absorbance was measured at $700 \mathrm{~nm}[7,8]$.

The results are shown in table 9.

Table 1: Dertermination of phytochemical screening

\begin{tabular}{|c|c|c|c|}
\hline Chemical test & Pet. ether & Chloroform & Ethanol \\
\hline Alkaloid & -ve & $+\mathrm{ve}$ & -ve \\
\hline Tannins & -ve & +ve & +ve \\
\hline Saponins & +ve & +ve & +ve \\
\hline Glycoside & -ve & -ve & +ve \\
\hline Carbohydrates & -ve & -ve & -ve \\
\hline Flavonoids & -ve & $+v e$ & -ve \\
\hline Proteins and amino acid & -ve & -ve & +ve \\
\hline Vitamin C(Ascorbic acid) & +ve & $+\mathrm{ve}$ & +ve \\
\hline Phenolics & +ve & +ve & +ve \\
\hline
\end{tabular}

*(+ve) and (-ve) symbol indicates the presence and absence of respective plant constituents.

\section{Thiobarbituric acid method}

\section{Procedure}

The test was conducted according to the method of Kikuzaki and Nakatani.

To $2.0 \mathrm{ml}$ of the Sample solution, $1.0 \mathrm{ml}$ of $20 \%$ aqueous trichloroacetic acid (TCA) and $2.0 \mathrm{ml}$ of Aqueous thiobarbituric acid (TBA) solution were added. Then the final sample concentration was $0.02 \% \mathrm{w} / \mathrm{v}$. The mixture was placed in a boiling water bath for $10 \mathrm{~min}$. After cooling, it was then centrifuged at $3000 \mathrm{rpm}$ for $20 \mathrm{~min}$. The absorbance of the supernatant was measured at $532 \mathrm{~nm}$. Antioxidant activity was recorded based on the absorbance of the final day of the FTC assay. Both methods (FTC and TBA) described antioxidant activity by percent inhibition: [9-10]

The results are shown in table 10 .

\section{1,1-Diphenyl-2-picryl hydrazil assay (DPPH assay)}

\section{Procedure}

The radical scavenging activity was determined by the use of DPPH free radical assay. Take $50 \mu \mathrm{L}$ of various concentrations of 
plant extracts in methanol were added to $5 \mathrm{ml}$ of $100 \mu \mathrm{L}$ Solution of DPPH in methanol. After 30 min incubation absorbance was read against blank taken as methanol at $517 \mathrm{~nm}$ and the \% inhibition was calculated from the following equation below [11, 12].

The results are shown in table 11.

\section{RESULTS}

Phytochemical screening

Phytochemical screening was carried out for petroleum ether, chloroform and ethanolic extract of Dillenia indica for the presence of different phytoconstituents like flavonoid, phenolic, carbohydrate, glycoside and proteins.

\section{Pharmacognostic evaluation}

Table 2: Determination of loss on drying

\begin{tabular}{llll}
\hline Wt. of porcelain & Initial wt. of the drug & Wt. of empty porcelain+drug before drying & Wt. of empty porcelain+drug after drying \\
\hline $118.32 \mathrm{gm}$ & $0.50 \mathrm{~g} / 500 \mathrm{gm}$ & $118.82 \mathrm{gm}$ & $118.80 \mathrm{gm}$ \\
\hline
\end{tabular}

Table 3: Determination of moisture content:

\begin{tabular}{llll}
\hline Wt. of the drug & $\begin{array}{l}\text { Initial wt. of the drug+pet dish } \\
\text { (gm) }\end{array}$ & $\begin{array}{l}\text { Constant wt. after drying } \\
\text { (gm) }\end{array}$ & $\begin{array}{l}\text { Loss on drying } \\
\text { (gm) }\end{array}$ \\
\hline $0.50 \mathrm{gm}$ & $11.82 \mathrm{gm}$ & $118.80 \mathrm{gm}$ & $0.02 \mathrm{gm}$ \\
\hline
\end{tabular}

Table 4: Determination of foaming index

\begin{tabular}{|c|c|c|c|c|c|c|c|c|c|c|}
\hline Concentration & $1 \mu \mathrm{g} / \mathrm{ml}$ & $\begin{array}{l}2 \\
\mu \mathrm{g} / \mathrm{ml}\end{array}$ & $3 \mu \mathrm{g} / \mathrm{ml}$ & $4 \mu \mathrm{g} / \mathrm{ml}$ & $5 \mu \mathrm{g} / \mathrm{ml}$ & $6 \mu \mathrm{g} / \mathrm{ml}$ & $7 \mu \mathrm{g} / \mathrm{ml}$ & $8 \mu \mathrm{g} / \mathrm{ml}$ & $9 \mu \mathrm{g} / \mathrm{ml}$ & $\begin{array}{l}10 \\
\mu \mathrm{g} / \mathrm{ml}\end{array}$ \\
\hline Test Results & -ve & -ve & -ve & -ve & -ve & -ve & -ve & +ve & $+\mathrm{ve}$ & $+\mathrm{ve}$ \\
\hline
\end{tabular}

Table 5: Determination of swelling index

\begin{tabular}{llll}
\hline Wt of coarse powder & Initial wt. of the powder & $\begin{array}{l}\text { Wt. of empty porcelain+drug before } \\
\text { drying }\end{array}$ & $\begin{array}{l}\text { Wt. of empty porcelain+drug after } \\
\text { drying }\end{array}$ \\
\hline $1-2 \mathrm{gm}$ & $0.50 \mathrm{~g} / 500 \mathrm{gm}$ & $118.82 \mathrm{gm}$ & $118.80 \mathrm{gm}$ \\
\hline
\end{tabular}

Table 6: Determination of ash values of a crude drug

\begin{tabular}{llllllcc}
\hline & $\begin{array}{l}\text { Wt. of } \\
\text { drug } \\
\text { (gm) }\end{array}$ & $\begin{array}{l}\text { Wt. of } \\
\text { crucible+drug } \\
\text { (gm) }\end{array}$ & $\begin{array}{l}\text { Wt. of } \\
\text { total ash } \\
\text { (gm) }\end{array}$ & $\begin{array}{l}\text { \% of } \\
\text { total } \\
\text { ash }\end{array}$ & $\begin{array}{l}\text { Wt. of acid } \\
\text { insoluble ash } \\
\text { value (gm) }\end{array}$ & $\begin{array}{l}\text { \% of acid } \\
\text { insoluble ash }\end{array}$ & $\begin{array}{l}\text { Wt. of water } \\
\text { soluble ash } \\
\text { value (gm) }\end{array}$ \\
\hline Crucible 1 & 2 & 22.19 & 1.6 & 1.8 & 22.1 & 0.18 & - \\
Crucible 2 & 2 & 27.85 & 1.9 & 8.5 & - & - & 23.8 \\
\hline
\end{tabular}

Table 7: Determination of fluorescence powder drug analysis

\begin{tabular}{|c|c|c|c|}
\hline Chemical test & Daylight & Short UV (254 nm) & Long UV (365 nm) \\
\hline Powder+1N NAOH in methanol & MOON YELLOW & HAUSER LIGHT & LEMONETE \\
\hline Powder $+1 \mathrm{~N} N A O H$ in $\mathrm{H} 20$ & RED & HAUSER MEDIUM & LEMONATE \\
\hline Powder+1N HCLin methanol & GEROGIA CLAY & OLIVE GREEN & AVOCADO \\
\hline Powder+1N HCL in H2O & YELLOW ORCHE & SOFT SAJE & DARK CHOCOLATE \\
\hline Powder $+1 \mathrm{~N}$ HNO3 in methanol & GEROGIA CLAY & HAUSER LIGHT & AVOCADO \\
\hline Powder $+1 \mathrm{~N}$ HCLin $\mathrm{H} 2 \mathrm{O}$ & SOFT SAFE & LEMONATE & DARK CHOCOLATE \\
\hline Powder $+5 \%$ Iodine & COCOA & OLIVE GREEN & AVOCADO \\
\hline Powder $+50 \% \mathrm{KOH}$ & COUNTRY RED & HAUSER MEDIUM & HAUSER LIGHT \\
\hline Powder $+5 \% \mathrm{FeCl} 3$ & DARK CHOCOLATE & GREEN & ARBOR GREEN \\
\hline
\end{tabular}

\section{DETERMINATION}

Table 8: The \% of the yield of different extracts of Dillenia indica roots

\begin{tabular}{lll}
\hline S. No. & Extracts & \% Yield \\
\hline 1. & Petroleum ether & 7.1 \\
2. & Chloroform & 2.4 \\
3. & Ethanol & 4.7 \\
\hline
\end{tabular}

\footnotetext{
In vitro anti-oxidant studies

Reducing the power method
} 
Table 9: In vitro antioxidant activity of ascorbic acid (Stand.), pet ether, chloroform and ethanol extract of Dillenia indicia by RP method

\begin{tabular}{llllll}
\hline S. No. & Extracts & $\mathbf{2 0} \boldsymbol{\mu g} / \mathbf{m l}$ & $\mathbf{5 0} \boldsymbol{\mu g} / \mathbf{m l}$ & $\mathbf{1 0 0} \mathbf{\mu g} / \mathbf{m l}$ & $\mathbf{2 0 0} \mathbf{\mu g} / \mathbf{m l}$ \\
\hline 01 & Ascorbic acid (Stand.) & $34.32 \pm 0.001$ & $48.66 \pm 0.002$ & $56.23 \pm 0.001$ & $66.62 \pm 0.05$ \\
02 & Pet. Ether Extract & $33.43 \pm 0.002$ & $42.65 \pm 0.003$ & $50.27 \pm 0.012$ & $59.55 \pm 0.001$ \\
03 & Chloroform Extract & $19.23 \pm 0.020$ & $23.36 \pm 0.018$ & $26.22 \pm 0.022$ & $34.86 \pm 0.012$ \\
04 & Ethanol Extract & $25.56 \pm 0.002$ & $16.19 \pm 0.012$ & $18.38 \pm 0.019$ & $21.37 \pm 0.020$ \\
\hline
\end{tabular}

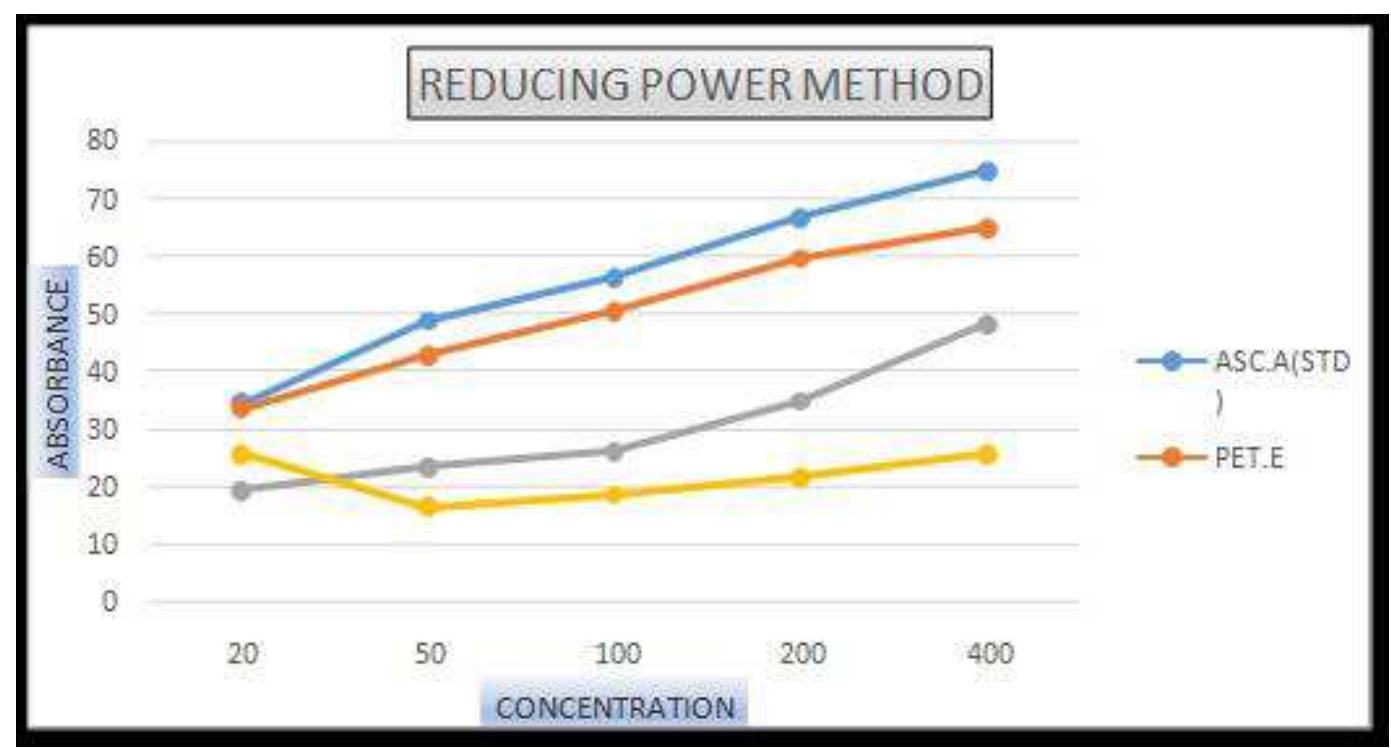

Fig. 1: Reducing power method of different extract of Dillenia indica

Thiobarbituric acid method

Table 10: In vitro antioxidant activity of ascorbic acid (Stand.), pet ether, chloroform and ethanol extract of Dillenia indicaby TBA method

\begin{tabular}{llllll}
\hline S. No. & Extracts & $\mathbf{2 0} \mathbf{\mu g} / \mathbf{m l}$ & $\mathbf{5 0} \boldsymbol{\mu g} / \mathbf{m l}$ & $\mathbf{1 0 0} \boldsymbol{\mu g} / \mathbf{m l}$ & $\mathbf{2 0 0} \boldsymbol{\mu g} / \mathbf{m l}$ \\
\hline 01 & Ascorbic acid (Stand.) & $34.32 \pm 0.001$ & $48.66 \pm 0.002$ & $56.23 \pm 0.001$ & $66.62 \pm 0.05$ \\
02 & Pet. Ether Extract & $15.55 \pm 0.021$ & $26.09 \pm 0.017$ & $33.023 \pm 0.023$ & $37.151 \pm 0.013$ \\
03 & Chloroform Extract & $14.228 \pm 0.012$ & $17.506 \pm 0.013$ & $27.028 \pm 0.014$ & $36.228 \pm 0.007$ \\
04 & Ethanol Extract & $18.470 \pm 0.016$ & $24.330 \pm 0.016$ & $34.123 \pm 0.024$ & $50.220 \pm 0.024$ \\
\hline
\end{tabular}

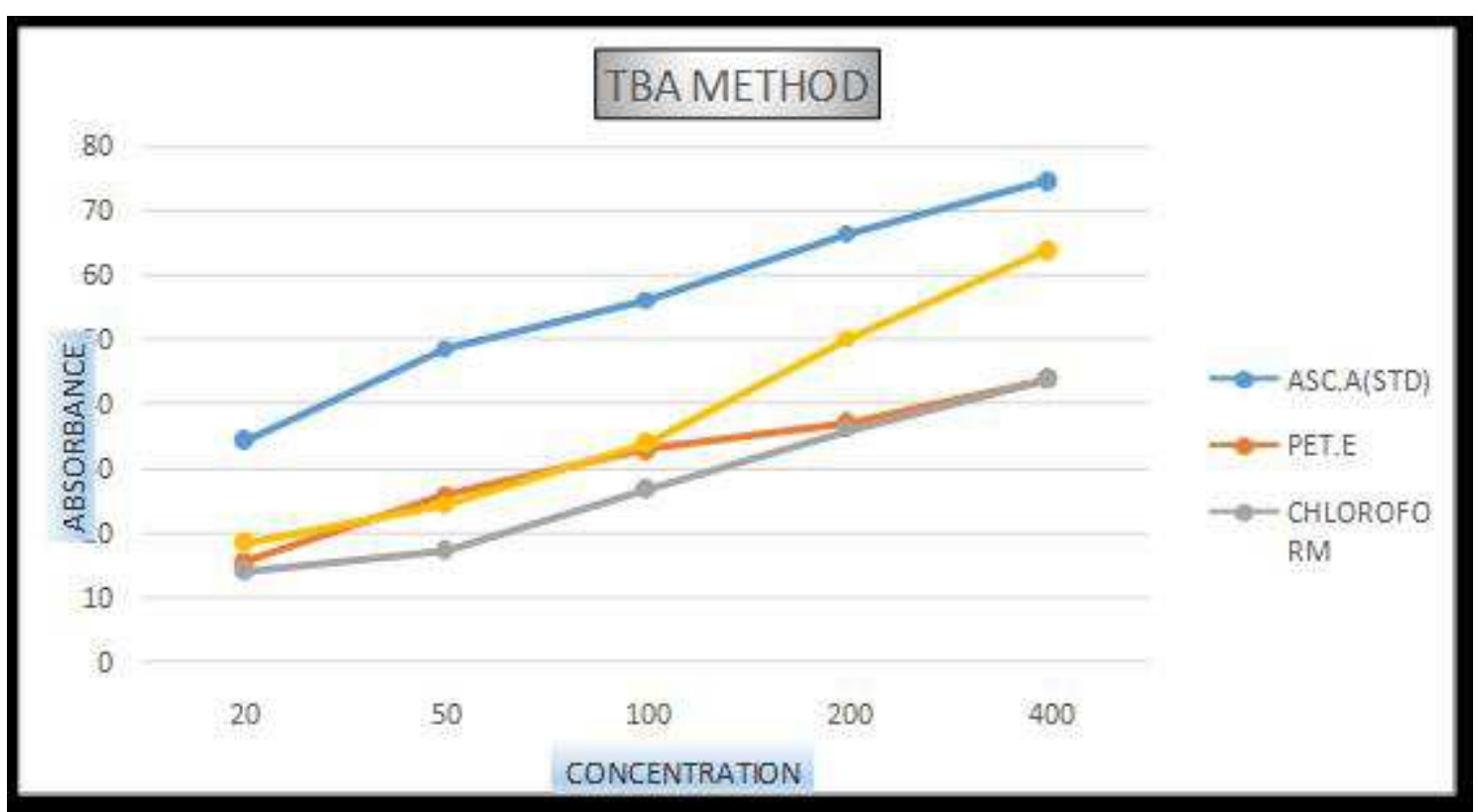

Fig. 2: TBA method of different extract of Dilleniaindica 
DPPH assay method

Table 11: In vitro antioxidant activity of ascorbic acid (Stand.), Pet ether, chloroform and ethanol extract of Dillenia indicia by DPPH ASSAY method

\begin{tabular}{llllll}
\hline S. No. & Extracts & $\mathbf{2 0} \boldsymbol{\mu g} / \mathbf{m l}$ & $\mathbf{5 0} \boldsymbol{\mu g} / \mathbf{m l}$ & $\mathbf{1 0 0} \boldsymbol{\mu g} / \mathbf{m l}$ & $\mathbf{2 0 0} \boldsymbol{\mu g} / \mathbf{m l}$ \\
\hline 01 & Ascorbic acid (Stand.) & $34.32 \pm 0.001$ & $48.66 \pm 0.002$ & $56.23 \pm 0.001$ & $66.62 \pm 0.05$ \\
02 & Pet. Ether Extract & $11.23 \pm 0.02$ & $16.06 \pm 0.008$ & $18.04 \pm 0.020$ & $22.36 \pm 0.025$ \\
03 & Chloroform Extract & $33.36 \pm 0.005$ & $46.09 \pm 0.006$ & $50.61 \pm 0.016$ & $61.56 \pm 0.002$ \\
04 & Ethanol Extract & $25.36 \pm 0.001$ & $30.44 \pm 0.003$ & $36.33 \pm 0.003$ & $46.89 \pm 0.01$ \\
\hline
\end{tabular}

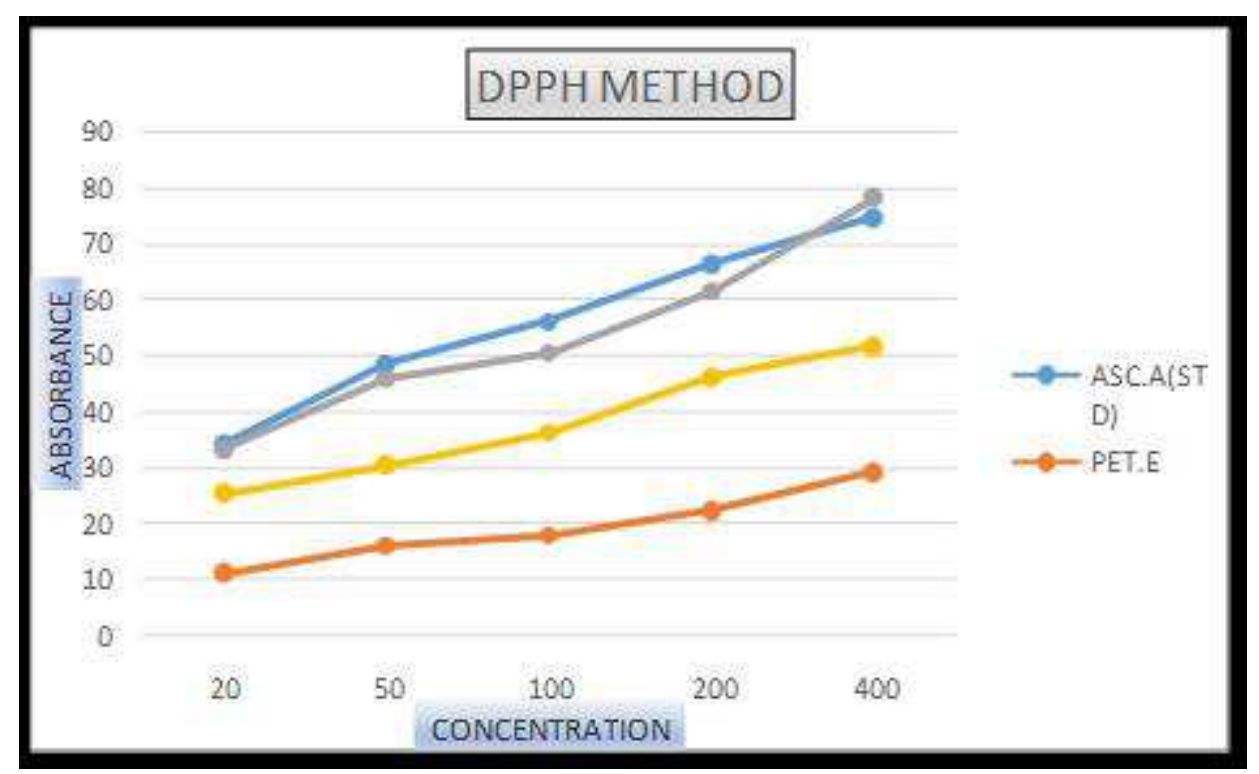

Fig. 3: DPPH scavenging activity of different extract of Dilleniaindica

Table 12: IC $\mathrm{I}_{50}$ value from reducing power method, tba method and DPPD scavenging activity of Dilleniaindica

\begin{tabular}{|c|c|c|c|}
\hline S. No. & Activity & Extract & IC50 \\
\hline \multirow[t]{4}{*}{01} & Reducing Power & Ascorbic acid(stnd) & 2.38 \\
\hline & & Pet. Ether & 2.98 \\
\hline & & Chloroform & 5.81 \\
\hline & & Ethanol & 62.1 \\
\hline \multirow[t]{4}{*}{02} & TBA & Ascorbic acid(stnd) & 2.38 \\
\hline & & Pet. Ether & 5.76 \\
\hline & & Chloroform & 5.83 \\
\hline & & Ethanol & 4.10 \\
\hline \multirow[t]{4}{*}{03} & DPPH & Ascorbic acid(stnd) & 2.38 \\
\hline & & Pet. Ether & 10.23 \\
\hline & & Chloroform & 2.62 \\
\hline & & Ethanol & 4.72 \\
\hline
\end{tabular}

\section{DISCUSSION}

\section{Phytochemical screening}

The phytochemical screening of powdered roots of Dillenia indicaindicates the presence of active constituents. Solvent selection was made for root and extraction was performed. From this study, it may be concluded that petroleum ether, chloroform and ethanolic extracts of this root of plant (Dillenia indica) have various phytoconstituents which was shown in (table 1).

\section{Pharmacognostic evaluation}

The pharmacognostic evaluation of the roots of this plant Dillenia indica gives us a brief idea about the various potential pharmacognostic activities in the plant.

\section{Anti-oxidant activity}

The antioxidant activity of this roots of Dillenia indica by using different models gives us a positive response that the roots of the plant shows active anti-oxidant properties which was compared with reference standard Ascorbic acid.

\section{CONCLUSION}

The current study shows that petroleum ether, chloroform and ethanolic extract of Dillenia indica have significant anti-oxidant property. Dillenia indica is widely available and also cultivated in different region in the world. The scientific research suggests a huge biological potential of this plant. A detailed study on the pharmacognostical, phytochemical and antioxidant properties of the root have been discussed and also provided details evidence for use of this root in different diseases. These results also justify the use of roots in traditional medicines.

\section{ACKNOWLEDGMENT}

I consider it a great privilege andhonor to have had the opportunity to undergo the Project work in Girijananda Chowdhury Institute of Pharmaceutical Science, Guwahati, Assam. Hence, I would like to offer my heartiest thanks to Dr. Sumit Das; Assistant Professor, Department 
of Pharmaceutical Chemistry, Girijananda Chowdhury Institute of Pharmaceutical Science, Guwahati, Assam, for his valuable guide and suggestion and the Principal for conveying the work.

\section{AUTHORS CONTRIBUTIONS}

All the author have contributed equally

\section{CONFLICT OF INTERESTS}

Declare none

\section{REFERENCES}

1. CP Kala. Current status of medicinal plants used by traditional vaidyas in Uttaranchal state of India. Ethnobot Res Appl 2005;2:267-78.

2. R Capasso, AA Izzo, L Pinto, T Bifulco. Phytotherapy and quality of herbal medicine. Fitoterapia 2000;71 Suppl 1:S58-65.

3. M Tamer, G Sanjay. Traditional knowledge and use of medicinal plants in the eastern desert of Egypt: a case study from. Wadi El-Gemal National Park 2013;1:10-7.

4. K Bisht, RS Rawal, U Dhar. Prioritization and conservation of Himalayan medicinal plants: Angelica glauca Edgew. As a case study. Ethnobot Res Appl 2006;4:11-23.
5. K Kokate, AP Purohit. A textbook of pharmacognosy. Nirali Prakashan; 2014. p. 25.

6. Jose S. Pandiammal. J Academia and Industrial Research; 2016. p. 2278-5213.

7. P Nimse, P Dilipkumar. Free radicals, natural antioxidants, and their reaction mechanism. Institute Appl Chem, Department Chem 2015;5:27986-8006.

8. PR Shankar. Anti-oxidant activity of Dillenia Indica linn. Asian J Pharm Life Sci 2012;2:360-4.

9. MH Abdille, RP Singh, GK Jayaprakasha. Antioxidant activity of the extracts from Dillenia indica fruits. Food Chem 2005; 90:891-6.

10. R Arbianti, TS Utami, A Kurmana. Comparison of antioxidant activity and total phenolic content of Dillenia indica leaves extracts obtained using various techniques. Proceedings of the 14th Regional Symposium on Chemical Engineering; 2007;92:851-66.

11. SB Boozer, GS Hammond, CE Hamilton, JN Sen. Air oxidation of hydrocarbons 1II. The stoichiometry and fate of inhibitors in benzene and chlorobenzene. J Am Chem Soc 1995;77:3233-43.

12. MH Abdille, RP Singh, GK Jayaprakasha, BS Jena. Antioxidant activity of the extracts from Dillenia indica fruits. Food Chem 2005;90:891-6. 